\title{
TINGKAT KESESUAIAN PROSES PELAYANAN RESEP DI UNIT FARMASI RAWAT JALAN TERHADAP STANDAR PROSEDUR OPERASIONAL DI RUMAH SAKIT
}

\author{
Gugus Virianti \\ Fakultas Farmasi Universitas Airlangga \\ email: guestveiry@gmail.com
}

\begin{abstract}
Prescription service is an important part in ensuring the success of patient therapy. In addition, prescription service is also a complex process because it requires precision and accuracy in each of its activities. Therefore, a Standard Operating Procedure (SOP) is needed to guide the prescription service process. The aim of this study is to evaluate the suitability of the prescription service process in outpatient pharmacy unit of a hospital based on SOP. The type of this research was an observational. Data were collected in August 2018 crosssectionally. Samples were taken by simple random sampling whose research population were all of outpatient prescriptions. The inclusion criteria were the prescription listed in the prescription service SOP. The exclusion criteria are prescription that were not listed in the prescription service SOP. Data were collected using observation instruments to evaluate the process of receiving prescription, medicine preparation and dispensing. Furthermore, the data were analyzed descriptively using a comparison of the level of suitability with SOP. The results obtained was that 372 prescriptions meet the inclusion criteria. Prescriptions were received based on SOP (6,5\%), prescriptions were prepared based on SOP (22,8\%), prescriptions were labeled based on SOP $(33,6 \%)$ and prescriptions dispensed based on SOP (20,7\%). There not all prescriptions are served based on SOP. The biggest discrepancy with the SOP was the process of checking prescriptions and rechecking. Discrepancy with SPO was caused by the lack of pharmacists, the high workload of pharmacists and lack of accessibility to SOP documents.
\end{abstract}

Keywords: Prescription Service; Standard Operating Procedures; Outpatient

\begin{abstract}
Abstrak: Pelayanan resep merupakan bagian penting dalam menjamin keberhasilan terapi pasien. Selain itu, pelayanan resep juga merupakan proses yang kompleks karena membutuhkan ketelitian dan kecermatan dalam setiap aktivitasnya. Oleh karena itu, dibutuhkan suatu Standar Prosedur Operasional (SPO) sebagai panduan proses pelayanan resep. Tujuan penelitian ini adalah mengevaluasi kesesuaian pelayanan resep di farmasi rawat jalan rumah sakit terhadap SPO. Jenis penelitian ini adalah observasional. Pengambilan data dilakukan secara potong-lintang pada bulan Agustus 2018. Teknik pengambilan sampel dilakukan secara acak dengan populasi penelitian adalah seluruh resep untuk pasien rawat jalan. Kriteria inklusi yang ditetapkan yaitu resep yang tercantum dalam SPO pelayanan resep. Kriteria eksklusinya yaitu resep yang tidak tercantum dalam SPO pelayanan resep. Data diambil menggunakan instrumen observasi untuk evaluasi proses penerimaan resep, penyiapan dan penyerahan obat. Selanjutnya data dianalisis secara deskriptif menggunakan perbandingan tingkat kesesuaian terhadap SPO. Hasil penelitian diperoleh 372 resep yang memenuhi kriteria inklusi. Resep yang diterima sesuai SPO $(6,5 \%)$, resep yang disiapkan obatnya sesuai SPO $(22,8 \%)$, resep yang disiapkan etiketnya sesuai SPO $(33,6 \%)$, resep yang obatnya diserahkan kepada pasien sesuai SPO (20,7\%). Belum seluruhnya resep dilayani sesuai SPO, ketidaksesuaian terbesar terhadap SPO terjadi pada proses mengkaji resep dan mengkaji ulang resep. Ketidaksesuaian proses pelayanan resep terhadap SPO disebabkan oleh kurangnya jumlah apoteker dan tingginya beban kerja apoteker serta kurangnya aksestabilitas terhadap dokumen SPO.
\end{abstract}

Kata kunci: Pelayanan Resep; Standar Prosedur Operasional; Rawat Jala 


\section{Pendahuluan}

Pelayanan resep merupakan bagian penting dalam terapi karena berkaitan dengan ketepatan pengobatan pasien. Menurut Permenkes no. 72 tahun 2016, pelayanan resep merupakan tanggung jawab apoteker untuk menyediakan obat yang tepat kepada pasien sesuai rencana perawatan yang diminta oleh dokter. Proses pelayanan resep dimulai sejak pasien menyerahkan resep sampai obat diserahkan kepada pasien (Spivey, 2012). Terdapat tahapan kritis yang berpengaruh pada proses pelayanan resep diantaranya: menerima dan menilai resep, mengkaji profil pengobatan pasien, memasukkan data resep ke komputer, memilih obat yang diperlukan pasien, menghitung dosis obat, memberi label, memeriksa ulang resep, assessmen pasien dan memberi konseling kepada pasien (Shah, 2010). Dalam permenkes 72 tahun 2016 dinyatakan bahwa pada setiap tahap alur pelayanan resep harus dilakukan upaya pencegahan terjadinya kesalahan pemberian obat (medication error). Kesalahan yang terjadi pada proses pelayanan resep dapat mengakibatkan kegagalan terapi atau bahkan cedera pasien (Shah, 2010).

Upaya untuk mencegah kesalahan pada setiap tahap pelayanan resep dengan melakukan aktivitas sesuai standar prosedur operasional/ SPO (Kemenkes, 2011). SPO dibutuhkan untuk menjamin kualitas pelayanan, kesinambungan proses, meminimalkan kesalahan yang mungkin terjadi karena salah tafsir atau miskomunikasi informasi, menghindari campur aduk prosedur, menghindari kebingungan dan berfungsi sebagai alat vital untuk mentransfer pengetahuan dan ketrampilan (Amare, 2012). SPO pelayanan resep menurut pedoman Cara Pelayanan Kefarmasian yang Baik (CPFB) Kemenkes (2011) terdiri dari tiga tahap yaitu skrining resep, penyiapan obat dan penyerahan obat oleh apoteker.

Fakta yang diperoleh menemukan adanya ketidaksesuaian pelayanan resep terhadap SPO diantaranya penelitian Kurniasih (2016) menemukan bahwa pemberian informasi obat pada proses pelayanan resep di RS X di Bogor sangat kurang dan tidak sesuai SPO-nya, diantaranya informasi lama terapi hanya $7,6 \%$, interaksi obat $1 \%$, efek samping obat 1\%. Stiyawan (2018) menemukan bahwa terdapat 11 poli $(61 \%)$ tidak melakukan alur pelayanan rawat jalan yang sesuai dengan SPO. Hal yang sama juga terjadi di RSJ Prof. Dr. Hb.sa'anin Padang dimana sebagian besar $(76,9 \%)$ responden penelitian tidak melaksanakan SPO dalam menjalankan tugasnya (Fidora, 2011). Thomas, C.E.L., et.al (2016) mengungkapkan bahwa ada beberapa faktor yang mempengaruhi kepatuhan petugas farmasi dalam menjalankan SPO diantaranya tuntutan pekerjaan, beban kerja yang tinggi, norma sosial di dalam apotek, kurangnya staf, tekanan untuk mencapai target dan komunikasi yang buruk.

Berdasarkan latar belakang ini maka perlu dilakukan evaluasi kesesuaian pelayanan resep di rumah sakit di Indonesia terhadap SPO.

\section{Metode}

Penelitian ini merupakan penelitian observasional dengan menggunakan metode potong-lintang (cross sectional). Penelitian dilakukan di unit farmasi rawat jalan sebuah rumah sakit umum daerah di Jawa Timur pada bulan Agustus 2018. Populasi penelitian adalah resep yang dilayani di unit farmasi rawat jalan selama 1 minggu sejumlah 5001 resep. Blangko resep di unit farmasi telah dilengkapi dengan kolom untuk paraf terima resep (T), racik (R), etiket (E) dan serah obat (S) serta blangko pengkajian resep dan blangko verifikasi. Teknik pengambilan sampel adalah acak sederhana dengan perhitungan sampel berdasarkan rumus Lemeshow diperoleh sampel sebesar 428 resep. Adapun dari 428 resep yang diobservasi secara prospektif, terdapat 372 resep yang memenuhi kriteria 
inklusi. Kriteria inklusi yaitu resep yang tercantum dalam SPO pelayanan resep. Adapun kriteria eksklusi yaitu resep yang tidak tercantum dalam SPO pelayanan resep. Instrumen yang digunakan untuk mengukur kesesuaian berupa checklist kesesuaian. Checklist dikembangkan peneliti dari langkah-langkah yang tertera dalam SPO. Selanjutnya data kesesuaian proses pelayanan resep terhadap SPO dianalisis secara deskriptif. Secara umum, checklist mengukur tiga aspek pelayanan resep yaitu penerimaan resep, penyiapan obat dan penyerahan obat.

Rumah sakit dalam penelitian ini memiliki SPO sebagai petunjuk teknis pelaksanaan pelayanan resep. Ketiga elemen tersebut diterjemahkan di SPO kedalam 10 langkah yaitu:

1) Menerima resep dari pasien;

2) Memberi paraf penerima pada kolom terima resep $(\mathrm{T})$;

3) Melakukan pengkajian resep dan menuliskan hasil kajian di blangko pengkajian resep;

4) Menyiapkan obat dan alat kesehatan sesuai resep;

5) Membubuhkan paraf petugas yang menyiapkan obat di kolom racik obat (R);

6) Memberi etiket pada sediaan obat;

7) Membubuhkan paraf petugas yang menulis etiket di kolom etiket (E);

8) Melakukan kaji ulang/verifikasi obat sebelum diserahkan kepada pasien dan mencatat hasil kajian pada blangko verifikasi;

9) Menyerahkan obat kepada pasien dan memberi informasi;

10) Membubuhkan paraf petugas yang menyerahkan obat obat di kolom serah obat (S).

Sepuluh langkah tersebut dapat diringkas dengan menggabungkan prosedur yang bersifat subtantif dengan administratif ditunjukkan pada Tabel 1.
Tabel 1. Ringkasan Prosedur Pelayanan Resep

\begin{tabular}{|c|c|c|}
\hline No & Prosedur Ringkasan & Prosedur \\
\hline \multicolumn{3}{|c|}{ Penerimaan Resep } \\
\hline 1 & $\begin{array}{l}\text { Menerima resep dari pasien } \\
\text { dibuktikan dengan paraf di } \\
\text { kolom terima resep }(\mathrm{T})\end{array}$ & 1 dan 2 \\
\hline 2 & $\begin{array}{l}\text { Melakukan pengkajian resep } \\
\text { dibuktikan dengan isian hasil } \\
\text { kajian di blangko pengkajian } \\
\text { resep }\end{array}$ & 3 \\
\hline \multicolumn{3}{|c|}{ Penyiapan Obat } \\
\hline 3 & $\begin{array}{l}\text { Menyiapkan obat dan alat } \\
\text { kesehatan sesuai resep } \\
\text { dibuktikan dengan paraf di } \\
\text { kolom racik obat }(\mathrm{R})\end{array}$ & 4 dan 5 \\
\hline 4 & $\begin{array}{l}\text { Memberi etiket pada sediaan } \\
\text { obat dibuktikan dengan paraf di } \\
\text { kolom etiket (E) }\end{array}$ & 6 dan 7 \\
\hline \multicolumn{3}{|c|}{ Penyerahan Obat } \\
\hline 5 & $\begin{array}{l}\text { Melakukan kaji ulang } \\
\text { dibuktikan dengan isian hasil } \\
\text { kajian ulang pada blangko } \\
\text { verifikasi }\end{array}$ & 8 \\
\hline 6 & $\begin{array}{l}\text { Menyerahkan obat pada pasien } \\
\text { dibuktikan dengan paraf di } \\
\text { kolom serah obat }(\mathrm{S})\end{array}$ & 9 dan 10 \\
\hline
\end{tabular}

\section{Hasil dan Pembahasan}

Hasil observasi proses pelayanan resep di salah satu rumah sakit umum daerah di Jawa Timur ditunjukkan pada Tabel 2 di bawah ini.

Tabel 2. Profil Kesesuaian Proses Pelayanan Resep dengan SPO $(n=372)$

\begin{tabular}{|c|c|c|c|}
\hline \multirow[t]{2}{*}{ No } & \multirow{2}{*}{$\begin{array}{c}\text { Proses Pelayanan Resep } \\
\text { Menurut SPO }\end{array}$} & \multicolumn{2}{|c|}{$\begin{array}{c}\text { Jumlah } \\
\text { Resep n }(\%)\end{array}$} \\
\hline & & Ya & Tidak \\
\hline \multicolumn{4}{|c|}{ Penerimaan Resep } \\
\hline 1 & $\begin{array}{l}\text { Menerima resep dari pasien } \\
\text { dibuktikan dengan paraf di } \\
\text { kolom terima resep }(\mathrm{T})\end{array}$ & $\begin{array}{c}24 \\
(6,5)\end{array}$ & $\begin{array}{c}348 \\
(93,5)\end{array}$ \\
\hline 2 & $\begin{array}{l}\text { Melakukan pengkajian } \\
\text { resep dibuktikan dengan } \\
\text { isian hasil kajian di blangko } \\
\text { pengkajian resep }\end{array}$ & $0(0)$ & $\begin{array}{c}372 \\
(100)\end{array}$ \\
\hline \multicolumn{4}{|c|}{ Penyiapan Obat } \\
\hline 3 & $\begin{array}{l}\text { Menyiapkan obat dan alat } \\
\text { kesehatan sesuai resep } \\
\text { dibuktikan dengan paraf di } \\
\text { kolom racik obat }(\mathrm{R})\end{array}$ & $\begin{array}{c}85 \\
(22,8)\end{array}$ & $\begin{array}{c}287 \\
(77,2)\end{array}$ \\
\hline 4 & $\begin{array}{l}\text { Memberi etiket sediaan obat } \\
\text { dibuktikan dengan paraf di } \\
\text { kolom etiket (E) }\end{array}$ & $\begin{array}{c}125 \\
(33,6)\end{array}$ & $\begin{array}{c}247 \\
(66,4)\end{array}$ \\
\hline
\end{tabular}


Lanjutan Tabel 2. Profil Kesesuaian Proses Pelayanan Resep dengan SPO $(n=372)$

\begin{tabular}{|c|c|c|c|}
\hline \multirow[t]{2}{*}{ No } & \multirow{2}{*}{$\begin{array}{c}\text { Proses Pelayanan Resep } \\
\text { Menurut SPO }\end{array}$} & \multicolumn{2}{|c|}{$\begin{array}{c}\text { Jumlah } \\
\text { Resep n (\%) }\end{array}$} \\
\hline & & Ya & Tidak \\
\hline \multicolumn{4}{|c|}{ Penyerahan Obat } \\
\hline 5 & $\begin{array}{l}\text { Melakukan kaji ulang } \\
\text { dibuktikan dengan isian } \\
\text { hasil kajian ulang pada } \\
\text { blangko verifikasi }\end{array}$ & $0(0)$ & $\begin{array}{c}372 \\
(100)\end{array}$ \\
\hline 6 & $\begin{array}{l}\text { Menyerahkan obat pada } \\
\text { pasien dibuktikan dengan } \\
\text { paraf di kolom serah obat } \\
\text { (S) }\end{array}$ & $\begin{array}{c}77 \\
(20,7)\end{array}$ & $\begin{array}{c}295 \\
(79,3)\end{array}$ \\
\hline
\end{tabular}

Berdasarkan Tabel 2 diketahui bahwa pada tahap penerimaan resep, hanya $6,5 \%$ resep yang diisi paraf di kolom terima resep (T) dan tidak ada isian di blangko pengkajian resep, artinya prosedur pembubuhan paraf di kolom $\mathrm{T}$ dan pengisian blangko pengkajian resep belum dilakukan dengan baik. Pada tahap penyiapan obat, hanya $22,8 \%$ resep yang diisi paraf di kolom racik obat $(\mathrm{R})$ dan $33,6 \%$ resep yang diisi paraf di kolom etiket (E), artinya prosedur pembubuhan paraf di kolom $\mathrm{R}$ dan E belum dilakukan dengan baik. Pada tahap penyerahan obat, tidak ada isian di blangko verifikasi pada semua resep dan hanya $20,7 \%$ resep yang diisi paraf di kolom serah obat (S), artinya prosedur pengisian blangko verifikasi dan pembubuhan paraf di kolom $S$ belum dilakukan dengan baik. Hal ini menunjukkan prosedur dokumentasi pada proses pelayanan resep di farmasi rawat jalan belum dilakukan dengan baik.

Proses pelayanan resep di farmasi rawat jalan dilakukan oleh 1 orang apoteker, 14 tenaga teknis kefarmasian dan 2 orang tenaga administrasi dengan jumlah resep yang dilayani rata-rata 834 resep/ hari. Apoteker bertugas sebagai koordinator di unit farmasi rawat jalan dan unit khusus hemodialisa. Selain itu apoteker di farmasi rawat jalan juga mempunyai tugas tambahan yaitu melayani resep obat tuberkulosis di poli paru dan sebagai pejabat penerima hasil pekerjaan di gudang farmasi. Profil keterlibatan petugas dalam pelayanan resep ditunjukkan oleh Tabel 3.
Tabel 3 Profil Aspek Pelayanan Resep Berdasarkan Kualifikasi Petugas

\begin{tabular}{|l|l|c|c|c|}
\hline \multirow{2}{*}{ No } & \multirow{2}{*}{ Pelayanan resep } & \multicolumn{3}{|c|}{$\begin{array}{c}\text { Jumlah Resep Yang } \\
\text { Dilayani n=372 }\end{array}$} \\
\cline { 3 - 5 } & & Apoteker & TTK & TA \\
\hline 1 & $\begin{array}{l}\text { Penerimaan } \\
\text { Resep }\end{array}$ & 0 & 59 & 313 \\
\hline 2 & Penyiapan Obat & 0 & 372 & 0 \\
\hline 3 & Penyerahan Obat & 18 & 354 & 0 \\
\hline
\end{tabular}

Keterangan:

TTK : Tenaga Teknis kefarmasian

TA : Tenaga Administrasi

Dari Tabel 3 diketahui bahwa sebagian kecil resep diterima oleh tenaga teknis kefarmasian dan sebagian besar resep diterima oleh tenaga administrasi. Semua resep disiapkan oleh tenaga teknis kefarmasian. Selanjutnya sebagian besar resep yang diserahkan obatnya oleh tenaga teknis kefarmasian dan hanya sebagian kecil diserahkan oleh apoteker. Pelayanan resep di rumah sakit yang dilakukan oleh tenaga teknis kefarmasian atau asisten apoteker juga terjadi di pelayanan masyarakat umum (yanmasum) Farmasi RSPAD Gatot Soebroto (Septini, 2012) dan unit farmasi rawat jalan RS Karya Bhakti Bogor (Elizabet, 2016). Tenaga yang ada di yanmasum Farmasi RSPAD Gatot Soebroto terdiri dari 1 orang apoteker sebagai manager pelayanan obat askes, 10 orang asisten apoteker (6 menangani pasien rawat jalan dan 4 menangani pasien rawat inap), 4 orang tenaga verifikasi, 1 orang tenaga administrasi gudang, 1 orang juru racik dan 2 orang kurir.

Menurut Permenkes No. 72 Tahun 2016 tentang standar pelayanan kefarmasian di rumah sakit dinyatakan bahwa pelayanan kefarmasian termasuk pelayanan resep harus dilakukan oleh apoteker dan atau dibantu tenaga teknis kefarmasian. Tenaga teknis kefarmasian yang melakukan pelayanan resep harus di bawah supervisi apoteker. Sedangkan tugas tenaga administrasi dalam instalasi farmasi rumah sakit adalah untuk melakukan pekerjaan penunjang misalnya operator komputer. 
Penerimaan resep seharusnya dilakukan oleh apoteker untuk melakukan pengkajian resep, menganalisa adanya masalah terkait obat namun saat menanyakan identitas pasien yang terdiri dari nama, alamat, dan informasi lain tentang pasien dapat dilakukan oleh petugas farmasi terlatih jika apoteker tidak ada. Pengkajian resep oleh apoteker secara signifikan dapat meningkatkan keselamatan pasien (Spivey, 2012). Menurut Kepmenkes No. 573 tahun 2008, pengkajian resep tidak termasuk dalam pekerjaan kefarmasian yang dapat dilimpahkan kepada tenaga teknis kefarmasian pada rumah sakit.

Jumlah apoteker di farmasi rawat jalan yang hanya satu orang dengan jumlah resep yang dilayani rata-rata 834/ hari menunjukkan jumlah apoteker belum memenuhi standar. Peraturan menteri kesehatan no 56 tahun 2014 tentang perizinan dan klasifikasi rumah sakit menyebutkan bahwa kebutuhan apoteker di farmasi rawat jalan rumah sakit tipe B minimal berjumlah 5 orang yaitu 1 orang apoteker sebagai koordinator 4 orang apoteker yang melakukan teknis. Penghitungan kebutuhan apoteker berdasarkan beban kerja pada pelayanan kefarmasian di rawat jalan yang meliputi pelayanan farmasi menajerial dan pelayanan farmasi klinik dibutuhkan tenaga apoteker dengan rasio 1 apoteker untuk 50 pasien (permenkes no 72 tahun 2016).

Hasil observasi di unit farmasi rawat jalan rumah sakit ini tidak ditemukan dokumen SPO pelayanan resep yang terpasang di ruangan. Dokumen SPO pelayanan resep tersimpan di dalam lemari yang terkunci dan sulit diakses oleh petugas. PermenPAN-RB No 35 Tahun 2012 menyebutkan bahwa salah satu langkah untuk menjamin keberhasilan pelaksanaan SPO adalah dengan membuat salinan/copy dari berbagai SPO yang dikembangkan dan mempermudah akses pihak-pihak terkait dalam implementasi SPO.

Faktor jumlah apoteker yang kurang dan beban kerja apoteker yang tinggi di farmasi rawat jalan rumah sakit tempat penelitian ini dapat mempengaruhi kepatuhan petugas farmasi dalam menjalankan SPO. Hal ini sejalan dengan pernyataan Thomas, C.E.L., et.al (2016) bahwa ada beberapa faktor yang mempengaruhi kepatuhan petugas farmasi dalam menjalankan SPO diantaranya tuntutan pekerjaan, beban kerja yang tinggi, norma sosial di dalam apotek, kurangnya staf, tekanan untuk mencapai target dan komunikasi yang buruk. Kualifikasi petugas pelayanan resep yang tidak sesuai standar dapat mempengaruhi pengetahuan dan pemahaman dalam menjalankan SPO pelayanan resep. Selain itu kemudahan mengakses dokumen SPO juga dapat mempengaruhi pelaksanaan SPO sebagaimana dinyatakan oleh Ulfa dan Sarzuli (2016) bahwa faktor ketidakpatuhan SPO meliputi lingkup internal dan eksternal. Faktor internal meliputi usia, jenis kelamin, masa kerja, pengetahuan, dan sikap. Sedangkan faktor eksternal meliputi faktor lingkungan kerja, karakteristik kelompok dan beban kerja.

Ketidaksesuaian paling besar dari proses pelayanan resep terhadap SPO (Tabel 2) adalah mengkaji resep pada tahap penerimaan resep dan mengkaji ulang resep pada tahap penyerahan obat. Mengkaji resep dan mengkaji ulang resep merupakan tahapan kritis yang berpengaruh pada proses pelayanan resep. Pengkajian resep oleh staf farmasi atau tenaga kesehatan yang salah dapat menimbulkan potensi risiko berupa salah obat, salah kekuatan, salah pasien, salah waktu dan salah rute. Adapun penyerahan obat yang dilakukan tanpa mengkaji ulang berpotensi menyebabkan cedera pasien ketika pasien tidak menerima obat mereka (Shah, 2010).

Ketidakpatuhan yang ditunjukkan oleh ketidaksesuaian terhadap SPO di farmasi rawat jalan di atas juga terjadi di tempattempat lain. Di rumah sakit $\mathrm{X}$ di Malang ditemukan 11 poli $(61 \%)$ tidak melakukan alur pelayanan rawat jalan yang sesuai dengan SPO (Stiyawan, 2018). Selain itu 
ketidaksesuaian terhadap SPO juga terjadi di rumah sakit Karya Bhakti Pratiwi Bogor (Elizabeth, 2016) dan di RSJ Prof. Dr. Hb.sa'anin Padang (Fidora, 2011).

Hasil penelitian yang menunjukkan ketidaksesuaian praktik terhadap SPO menggambarkan hilangnya urgensi SPO di proses pelayanan resep di farmasi rawat jalan rumah sakit ini. Spivey (2012) menyatakan bahwa SPO menjadi salah satu faktor penting dalam kualitas pelayanan farmasi. Selain itu, SPO seharusnya bermanfaat dalam mengurangi tingkat kesalahan dan kelalaian pegawai dalam bertugas, menjamin konsistensi mutu, waktu, dan prosedur pelayanan, dan membantu penelusuran kesalahan-kesalahan prosedural dalam memberikan pelayanan (Lampiran PermenPAN-RB Nomor 35 Tahun 2012). Selain itu, SPO yang ada seharusnya dapat mengatasi hambatan komunikasi/ miskomunikasi yang menjadi penyebab utama proses pelayanan resep (Gandage et al, 2018). Hal ini sejalan dengan Amare (2012) yang menyatakan bahwa standar dibutuhkan untuk menjamin kualitas pelayanan, kesinambungan proses, meminimalkan kesalahan yang mungkin terjadi karena salah tafsir atau miskomunikasi informasi, menghindari campur aduk prosedur, menghindari kebingungan dan berfungsi sebagai alat vital untuk mentransfer pengetahuan dan ketrampilan.

Penegakan SPO pelayanan resep di farmasi rawat jalan rumah sakit ini memerlukan beberapa langkah untuk menjamin keberhasilannya, antara lain perencanaan penerapan SPO, distribusi dan aksestabilitas, pelatihan pemahaman SPO, dan supervisi (Lampiran PermenPAN-RB No 35 Tahun 2012). Perencanaan penerapan SPO dilakukan untuk memberikan kesempatan setiap anggota organisasi yang berkepentingan dalam mempelajari dan memahami semua tugas, arahan, dan jadwal serta kebutuhan sumberdaya yang terkait. Distribusi dan aksesibilitas dilakukan dengan membuat salinan/copy dari berbagai
SPO yang dikembangkan untuk mempermudah akses pihak-pihak terkait dalam implementasi SPO yang baru. Pelatihan pemahaman SPO juga diperlukan untuk memberi motivasi, alih informasi, kesempatan untuk melatih keterampilan baru, dan peningkatan kemampuan. Supervisi dilakukan untuk memastikan SPO benar-benar dikuasai oleh para pelaksana.

Keterbatasan penelitian ini adalah beberapa aktivitas dalam proses pelayanan resep tidak dapat diobservasi dan dinterpretasikan hanya dari dokumentasi yang ada di resep, misalnya pengkajian resep. Untuk itu diperlukan studi dengan pendekatan lainnya, seperti menggunakan unit analisis petugas farmasi.

\section{Simpulan}

Dari 372 resep, resep yang diterima sesuai SPO $(6,5 \%)$, resep yang disiapkan sesuai SPO $(22,8 \%)$, resep yang disiapkan etiket sesuai SPO $(33,6 \%)$, resep yang obatnya diserahkan ke pasien sesuai SPO $(20,7 \%)$. Belum seluruhnya resep dilayani sesuai SPO, ketidaksesuaian terbesar terhadap SPO terjadi pada proses mengkaji resep dan mengkaji ulang resep. Ketidaksesuaian proses pelayanan resep terhadap SPO pada obyek penelitian ini disebabkan oleh kurangnya jumlah apoteker dan tingginya beban kerja apoteker serta kurangnya aksestabilitas terhadap dokumen SPO. Rekomendasi yang diberikan melakukan analisis beban kerja apoteker di farmasi rawat jalan rumah sakit serta menempatkan salinan SPO di ruang pelayanan resep.

\section{Daftar Pustaka}

Amare G. (2012). Reviewing The Values of a Standard Operating Procedure. Ethiopia Journal Health Science. 22(3): 205-208

Depkes. R.I., (2016). Peraturan Menteri Kesehatan No 72 tahun 2016 tentang Standar Pelayanan Kefarmasian di Rumah Sakit. Jakarta: Dirjen 
Pelayanan Kefarmasian dan Alat Kesehatan

Depkes. R.I. (2011). Peraturan Menteri Kesehatan No169/ MENKES/ PER/ VIII/ 2011 tentang Keselamatan Pasien Rumah Sakit. Jakarta

Depkes. R.I. (2011). Pedoman Pelayanan Kefarmasian yang Baik (CPFB). Jakarta

Depkes. R.I. (2008). Tanggung Jawab Apoteker Terhadap Keselamatan Pasien (Patient Safety). Jakarta.

Elizabeth, Y. 2016. Gambaran Sistem Pelayanan resep Pasien Di Instalasi Farmasi Rawat Jalan Rumah Sakit Karya Bhakti Pratiwi Bogor. Skripsi. UIN Syarif Hidayatullah Jakarta

Fidora. (2011). Faktor-faktor Kinerja yang Berhubungan dengan Pelaksanaan Standar Operasional Prosedur (SOP) Sindrom Defisit Perawatan Diri Pasien Oleh Perawat Pelaksana Di RSJ Prof. Dr. Hb. Sa'anin Padang Tahun 2010. Penelitian.

Gandage, Ninne, Salimath, Reddy, Buchanalli, Samson. (2018). A Study on Role of Clinical Pharmacist in Identification and Prevention of Medication Errors at Tertiary Care Hospital. Indian Journal of Pharmacy Practice, Vol 11, Issue 4

Keputusan Menteri Kesehatan Republik Indonesia Nomor 573/ Menkes/SK/VI/ 2008 tentang Standar Profesi Asisten Apoteker.

Kurniasih, Amalia, Anggraini. (2016). Analisis Mutu Pelayanan Farmasi Di Unit Farmasi Rawat Jalan Rumah Sakit X di Bogor. Social Clinical Pharmacy Indonesia Journal, Vol. 1 No.1.

Peraturan Menteri Kesehatan Republik Indonesia Nomor 56 tahun 2014 tentang Klasifikasi dan Perizinan Rumah Sakit.

Peraturan Menteri Pendayagunaan Aparatur Negara dan Reformasi Birokrasi Republik Indonesia nomor 35 tahun 2012 tentang pedoman penyusunan standar operasional prosedur administrasi pemerintahan

Septini, R. (2012). Analisis Waktu Tunggu Pelayanan Resep Pasien Askes Rawat Jalan Di Yanmasum Farmasi RSPAD Gatot Soebroto Tahun 2012. Tesis. Universitas Indonesia, Depok.

Spivey. (2012). Ensuring Good Dispensing Practice. Management Sciences For Health

Stiyawan, Mansur, Noor. (2018). Dampak Tidak Patuh Terhadap Pelaksanaan SOP Alur Rawat Jalan di Rumah Sakit "X" Malang. Jurnal Bisnis dan Manajemen. Vol 2 No 1.

Thomas CEL, Phipps DL, Ashcroft DM. (2016). When procedures meet practice in community pharmacies: qualitative insights from pharmacists and pharmacy support staff. BMJ Open, 2016;6:e010851. doi: 10.1136/b mjopen-2015-0108

Ulfa dan Sarzuli. (2016). Pengaruh Faktor Internal dan Eksternal Terhadap Kepatuhan Perawat Dalam Melaksanakan Standar Prosedur Operasional Pemasangan Kateter di Rumah Sakit PKU Muhammadiyah Yogyakarta Unit II. Jurnal Medicoeticolegal dan Manajemen Rumah Sakit, Vol 5 No 1. 